\title{
Factors Affecting Profitability of Fish Farming Under Economic Stimulus Programme in Tigania East District, Meru County, Kenya
}

\author{
Kimathi Antoney Njagi, Ibuathu Charles Njati, Guyo Huka S. \\ School of Business and Economics Meru University of Science and Technology P.O Box 972 Meru \\ School of Business \& Economics Meru University of Science and Technology P.O Box 972 Meru \\ School of Business \& Economics Meru University of Science and Technology P.O Box 972 Meru
}

\begin{abstract}
The purpose of this study was to investigate factors affecting profitability of fish farming under Economic Stimulus Programme in Tigania East District of Meru County, Kenya. In 2010, Economic Stimulus Programme was initiated by the Government of Kenya with the aim of encouraging fish farming in the region. The government spent more than 8 millions in fish farming in the district. The study was set to determine the influence of marketing on profitability of fish farming in Tigania East, establish the importance of related extension services on fish farming; determine the host's community cultural practises that influence fish farming and explore ways in which pond management skills influences fish farming.

Many people turned to fish farming as a source of food and income generating activity. However, where adopted as business there were little returns from fish farming. Descriptive research design was employed in the study. The study applied descriptive research design by involving 200 fish farmers within Tigania East district. Stratified random sampling was used to select fish farmers. The study established that respondents were positive about the sustainability and positive impact of fish farming on their lives. Despite the government support fish farmers faced challenges in terms of access to market, access to technical information, predators and inadequate extension services. The study concluded that the Government needs to provide technical capacity building, market accessibility to the practicing fish farmers in their localities.
\end{abstract}

Key words: Economic stimulus, Marketing, Extension services, Management skills

\section{Introduction And Background To The Study}

Fishing is one of the oldest economic occupations of mankind and is carried out for subsistence and commercial purposes. In developed countries it is highly commercialized while in developing countries it is mainly carried out for subsistence purposes. Fishing is carried out along all coastlines, in enclosed seas and in inland fresh waters. However, the main fishing grounds of the world are located in the cool waters of Pacific and Atlantic coasts within the temperate latitudes of northern hemisphere. Each account for $40 \%$ of the world's annual total fish hauls while Indian Ocean account for about $4 \%$. Aqua culture account for about $15 \%$. According to Food and Agriculture Organisation, (2008) throughout the centuries fish has been an important component of the population's diet in many parts of the world. Fish catches increased rapidly over the past hundred years due to improved technology, which provided more powerful engines and sonar equipment. This led to over fishing and caused a worldwide decrease in wild stocks. As a result, the growth in fish catches stopped some 20 years ago. The need to increase fish production by farming became therefore an urgent matter. According to FAO (2007), top producers of aquaculture are China, India, Viet Nam, Indonesia and Thailand. China, with one-fifth of the world's population, accounts for two-thirds of the worlds reported aquaculture production. China's 2005 reported harvest was 32.4 million tonnes, more than 10 times that of the secondranked nation, India, which reported 2.8 million tonnes (FAO, 2009). Since 2002, China has been the world largest exporter of fish and fish products. In 2005, exports, including aquatic plants, were valued at US\$7.7 billion, with Japan, the United States and the Republic of Korea as the main markets. In 2005, the total number of fish farmers 33 world-wide was about 12 million with China reported 4.5 million people employed full time in aquaculture. In the past, fish culture in China has been a family business with traditional techniques passed from generation to generation. However, in the late 1960s the Chinese government began a move to the modern induced breeding technologies such that fish grow rapidly and has a high feed conversion rate, which has resulted in a rapid expansion of freshwater aquaculture in China Weimin et al (2007).

Aquaculture was introduced to Sub-Saharan Africa in the 1950s with main objectives of improved nutrition in rural areas, generation of additional income, diversification of activities to reduce risk of crop failures and the creation of employment in rural areas (Hecht, 2006). About 43\% of the African continent is assessed as having the potential for farming tilapia, African catfish and carp (Ridler and Hishamunda, 2001). Though aquaculture has grown strongly in most regions of the world where the potential exists, it has not done 
so in Sub-Saharan Africa. In spite of various efforts since the 1950s, returns on government and international aquaculture investments appeared to be insignificant (FAO, 2004) with less than $5 \%$ of the suitable land area being used (Kapetsky, 2004). Sub-Saharan Africa contribution to world aquaculture production is less than 1\% (Hecht 2006).To support future needs, capture fisheries will need to be sustained and if possible enhanced, and aquaculture developed rapidly (Muir et al. 2005). However, a number of reasons have been suggested for the poor rate of growth in aquaculture development in the region. These include causes relating to fish consumption preferences, the general level of economic development in rural areas, the policy and governance environment, and limiting social factors (FAO, 2006), together with a lack of access to available information .

Egypt has built the largest aquaculture industry in Africa, accounting for four out of every five fish farmed on the continent, according to FAO report, 2008. The report further reveals that Egyptian fish farms produce over 650,000 tons of finfish per year, or about 60 per cent of the country's total freshwater and marine fish production, providing a cheap source of protein for the country's over 80 million people. The industry has witnessed explosive growth over the past decade. Total aquaculture production has grown by 500 percent since 1998 due to a shift to intensive rearing methods and faster growing species such as tilapia, Al-Ahram (2010). Aquaculture sector employs about 164,000 people, representing 3.07 percent of employment in agriculture and additional 20,000 people in supporting services and industries (FAO, 2008). Fisheries contribution to agriculture production was $7.34 \%$ of agricultural production and $20.9 \%$ of total livestock and poultry production by value in 2002 (Dey Briones and Ahmed, 2005).

Mwangi (2008) observes that fish farming implies some form of intervention in the rearing process to enhance production, such as regular stocking, feeding, and protection from predators among other interventions. Aquaculture has the same objective as agriculture, namely, to increase the production of food above the level that would be produced naturally. Today, aquaculture is responsible for an ever-increasing share of global aquatic food production, which has increased from 3.9 percent in 1970 to 31.9 percent in 2003 (FAO, 2005).

In Kenya warm water fish pond began as early as 1920's according to the findings of Ngugi, Bowman and Omollo (2007).Their findings continue to reveal that the government popularised aquaculture in 1960s through the "eat more fish" campaign. As a result, Tilapia fish farming expanded rapidly with the construction of many small ponds. However, this initiative failed in 1970's mainly because of inadequate extension services, lack of quality fingerlings and insufficient training of extension workers. By 1990 small scale fish farming followed a pattern similar to that in many other African countries characterized by small size ponds and low levels of production. According to Gitonga, Mbugua and Nyanditi (2004), Kenya aquaculture was carried at different levels from small hand dug kitchen ponds at subsistence level to other impounded used for water storage stocked with fish and harvested periodically. The findings of Howard and Omlin, (2007) show that fish farming in Kenya is still under developed with annual production of only 1,000 tonnes, a factor attributed to some regions like Western Kenya abandoning fish a pond leading to increase in malaria vector. This is because the abandoned ponds become a breeding place for mosquitoes.

Although Kenya is still faced with many challenges, development of aquaculture can play a leading role in poverty reduction, and also as a source of alternative fish instead of relying on natural ecosystem which is declining (Gitonga et al 2004). This idea has been enforced by the government with identification of small scale fish farming as one of the pillars of Economic Stimulus Programme identified to jump start the economy of Kenya. It is on this background that the government set aside Kshs 1.12 billion to construct 200 fish ponds in selected 140 constituencies across the country $(\mathrm{GoK}, 2009)$. This has changed most of the activities of people in areas which were not fish farming to start doing so. According to the findings of Wairimu, (2008) in her report entitled "voice of Africa-Meru town to modern fish farming", regions like Meru have adopted fish farming an activity which did not exist before. Despite the economic importance of fish farming and the government efforts some of the fish farmers have abandoned the activity or pay little attention to it due to some challenges that makes the venture not profitable.

\subsection{Statement of the Problem}

Today there are renewed interests in fish farming in Kenya, a fact contributed by the government's initiative of Economic Stimulus Programme. Farmers in aqua cultural potential areas across the country are turning to fish farming as a way of producing high quality food, either for their families or for the market, and a way of earning extra income. The small-scale farmers in some selected 140 constituencies have been the government's target.

However, despite the government's efforts some of the fish farmers have not fully reaped from the activity which has the potential due to some factors that makes the venture not profitable. Fish production is characterized by low pond productivity due to poor extension services, marketing problems, influence of cultural background and employment of low pond management practises. These challenges create poor perception of fish farming as an economic activity among many people thus most potential fish farmers are not 
convinced that aquaculture can be a profitable enterprise. It is against this background that this research evaluated some selected factors that affect the profitability of fish farming in Tigania East District.

\subsection{Objectives of the study}

Specific objectives of this study were:

1. To determine the influence of marketing on profitability of fish farming in Tigania East

2. To establish the importance of related extension services on fish farming

3. To determine the host's community cultural practises that influence fish farming

4. To explore ways in which pond management skills influences fish farming

\section{Review Of Related Literature}

The literature for this study was reviewed on the following thematic areas

\subsection{Fish farming as economic activity}

A study by Mwangi (2008) entitled “Aquaculture in Kenya” observes that, Fisheries sector contributes significantly to the National economy through employment creation, foreign exchange earnings, poverty reduction and food security support. The study further states that the sector contributed $0.5 \%$ to GDP in the year 2006. This contribution could be higher if value addition at the various stages of the supply chain are considered and post harvest losses minimized. The sub-sector's growth was estimated at $4.1 \%$ in 2005 (National Economic Survey,2006).

According to a study conducted by Mwangi (2008), the government has taken keen interest in fisheries due to its potential and has given it the priority it deserves. His sentiments are confirmed when by the government's incorporation of fish farming in the ESP to help jump start the economy by providing food and income to the rural inhabitants as a way of eradicating poverty and creating jobs to the poverty stricken areas (GoK, 2009). The programme target areas with high population, small farmland and mass poverty with low incomes and fluctuating farm productivity but with water available to sustain the programme.

Further, Ngugi et al (2008) in a study entitled "A New Guide to Fish Farming in Kenya", Kenya is endowed with numerous aquatic resources with aquaculture potential. The study continues to reveals that the country has varied climatic and geographical regions, covering part of Indian ocean coastline, a portion of the largest fresh water lake ( Victoria) and several large rivers, swamps and other wetland, all of which support abundance of native aquatic species. However, fish farming since its introduction under ESP has not made much further progress and has in many cases even declined resulting in the abandonment of fish ponds by discouraged farmers.

The Africa Regional Aquaculture Review Meeting (CIFA/OP24, FAO, 2000) identified a number of constraints affecting the development of the aquaculture sector in Africa. Among other things, the review concluded that Small-scale farmers have rural social constraints such as limited access to market, inadequate extension services, and poor pond management among others that affect their needs, priority assessments and aspirations.

These findings concur that despite the critical role played by aquaculture sector, it is faced with many challenges and constraints that include limited access to financial services and markets; inadequate access to skills and technology; insecurity of land tenure; poor access to infrastructure; inadequate business knowhow among others .The findings are too general and fail to specifically address fish farming under ESP which is a government's initiative and more so in the new areas where fish farming did not exist before, the case of Tigania East as an example, the study is particularly considered with whether these factors really affect profitability and not only fish farming, hence the necessity of this study.

\subsection{Marketing of fish}

According to FAO, (2008), Fish farming has become one of the most profitable and fast growing enterprise to run and has been an alternative to agriculture which depends on seasonal rainfall; fish farming is all season's enterprise that provides nutritious food, constant income and can help alleviate poverty. However, the report identifies the fish market as one major factor hindering the prosperity of the venture. According to FAO, marketing involves all the activities associated with getting fish to the consumers in the desired form, such as processing, packaging, transporting, storing, and other functions.

Learning institutions and health facilities in the locality are another important source of market for the subsistence fish farmers (Ngugi et al 2007). According to him it is advisable that small-scale producers form marketing groups, which will assure them a regular market. The same is echoed by the government in her advice to beneficiaries of economic stimulus programme to form clusters of local associations and if possible cooperative societies to market their products in order to achieve maximum benefits, (www.economic stimulus.go.ke). 
The findings by these scholars and institutions are in agreement that a major problem for many fish farmers is where to sell their fish. However, their findings fail to note that majority of fish farmers under ESP are new subsistence farmers who sell their fish locally at the pond site to their neighbours, this is after they meet their families demand. This fetch them low returns as they have nowhere else to take their products which is small in quantity due to the high transaction costs involved. An important aspect of fish market should include the cost alternative market outlet for the farmed fish and this is best done by the formation of special organizations simply the fish assembly centres, where they can have a bargaining power.

According to Ngugi et al (2007), before starting a fish farming enterprise, a farmer should conduct a market survey to help determine:

- Type and size of fish preferred by consumers (fingerlings, whole-fish, fillets, etc.)

- Quantity of fish required by the market.

- Best time to market fish

- Which other farmers are supplying fish

- Prices at which fish are being sold

Their study puts forward a rule of the thumb which state that fresh farmed fishwhose source is known and whose quality is assured will fetch better prices in market.

It is important to note that fish farmers will want a marketing system that provides high quality fish on demand at the lowest cost, efficient and effective in delivery of services and reliable when needed. The value of fish can be added by doing some basic processing and this improves the market. Refrigeration is required to store the perishable fish, but it is beyond the reach of the ordinary fish farmers, hence it is advisable that the farmer take the fish to the market and sell as quickly as possible as holding the fish for too long will spoil it by producing bad smell and even becomes harmful for consumption.

Mwangi (2008), notes that aquaculture product diversification and value addition are not fully developed. His study recommends that government need to develop market infrastructure, build capacity support to farmers, organise promotion through trade fairs, develop market information systems, promote and facilitate value addition for aquaculture products ,however he fails to identify how and what the measures the government will put in place noting that the ministry of fisheries is understaffed.

The study by the above authors failed to consider that under ESP , most of fish farms are in new rural areas where Poor infrastructure as evidenced by poor state of road network is a critical factor that constrains profitable businesses, for example, adds to the cost of producing and marketing of goods and services, thereby rendering them less competitive. These studies further fail to associate marketing with relevant marketing information which is crucial to help access new markets and address the issue of technology which is expensive to them in order to produce quality products which are competitive in the market, thus the contention of the study.

\subsection{Extension services}

Gitonga et al, (2004) indicates that the government popularised aquaculture in 1960's through the "eat more fish" campaign. However this did not achieve much in increasing fish production. One of the major challenges was inadequate extension services, lack of quality fingerlings and insufficient training of extension workers.This observation is supported by the fact that there is inadequate staffing in the ministry of fisheries development (GoK, 2009)

A study conducted on Aquaculture extension service in Kenya by C.C. Ngugi and J.O. Manyala (2004), one of the biggest constraints facing aquaculture development is the lack of extension staff and infrastructure to deliver technical knowledge about aquaculture to rural smallholders. The study further reveals that technical aspects of constructing even small ponds of the appropriate size and depth, and ensuring that they will have suitable sources of water, filtration and aeration is complex, requiring significant education and extension support. Ngugi and Manyala's study concluded that aquaculture extension services provided mainly through the Fisheries Department programmes have been found to be too inadequate to disseminate the improved aquaculture technology packages throughout the country. In Kenya, aquaculture systems are characterized by poor quality fish seeds, low inputs, low density of stocking, stunting in tilapias and partial harvests all leading to poor fish production per unit area. There has been a total failure of policy orientation in both research and extension efforts towards what are technically feasible.

Despite the government acknowledging inadequate extension services in the fisheries department, the ESP project on fish farming was initiated even without first addressing the issue of inadequate and trained extension workers. In some districts, (Tigania East included) there are no district fisheries officers and are forced to rely on one officer who may be serving more than four districts. Others have one field officer who may be lacking means of transport to enable service delivery in the whole region. 
The available findings by scholars and government reports indicate lack of adequate extension services in the fish farming sector. Thus there is a rationale to investigate how the farmers go about their daily fish farming activities without this crucial component and how its absence has affected their enterprise's profitability.

\subsection{Economic stimulus programme (E.S.P)}

It is a short to medium term, high intensity and impact programme aimed at jump starting the economy towards long term growth and development, securing the livelihood of Kenyans and addressing the challenges of regional and inter-generational inequity. The programme focuses on sectors that will generate maximum benefit, restore confidence and assist the business community to weather the storm, while protecting the livelihood of poor and creating job s to the youth, (GoK, 2009). Some of the activities covered under ESP include expansion of irrigation based agriculture, construction of wholesale and fresh produce market, fish ponds and jua kali sheds. Key objectives of ESP include: boosting of the country's economic recovery and return the economy to envisioned medium term growth plan, invest in long term solution to the challenges of food security, expand economic opportunities in rural areas for employment creation, and promoting regional development of equity and social stability.

The fish farming project is intended to improve nutrition and create over 120,000 employment and income opportunities. 200 fish ponds have been constructed in each of the selected constituencies at an estimated cost of Ksh.12 millions per constituency and Tigania East district included. In these districts fish farmers are funded with kshs. 40,000 to construct a pond, provided with free 1,000 fingerlings and free fish feeds .The ministry of fisheries is taking a lead role in the project, (Fish Farming Enterprise and Productivity Report, 2010).

According to Rebecca D.A (2010) in her study entitled "fish farming as a means of boosting the economy of Kisumu County, Kenya" The majority of fish farmers are supported by the Government of Kenya, through the Economic Stimulus Programme. In the Economic Stimulus Plan, the Government provided each fish farmer with 1000 fingerlings, fish feeds and constructed a pond for each fish farmer. Most of the fish farmers are in their first cycle of fish farming and are yet to realise their returns due to various challenges that they face. These studies observed that for fish farming to be a sustainable venture in the region, it is crucial that the government provides information to the fish farmers, beyond the initial support that they received. The need for relevant technical information by the fish farmers cannot be emphasised enough. The fish farmers need to be educated on which species are best suited to their sites, how to care for the fingerlings and weigh them, how to care for the ponds and dispose of waste from their fish farms. Fish farmers need to be provided with support which could be in the form of marketing channels, improvement of infrastructure, and information provision.

\section{Theoretical and conceptual frameworks}

The study will be based on the broad frame work of the theory of constraints (TOC), sometimes known as constraint analysis as advanced by Israeli physicist Eliyahu M. Goldratt.

According to Bushong, J. Gregory, and John C. Talbott, in their CPA Journal of April 1999 entitled, "An Application of the Theory of Constraints.", the theory of constraints (TOC) is a systematic and iterative approach to management that emphasizes adapting business practices in order to best cope with limitations, or constraints, that stand in the way of key objectives. The goal of TOC is to maximize the efficiency of a process selectively at the most critical points and thereby maximize profitability, quality, or other corporate objectives. The theory of constraints aims at optimizing profits and the use of resources.

\section{Conceptual frame work}

The conceptual frame work defines the variables of research and shows how independent variable influences the dependent variables. In this study conceptual frame work show how factors such as marketing, extension services, cultural practices and pond management limits entrepreneurs' profitability in fish farming. 


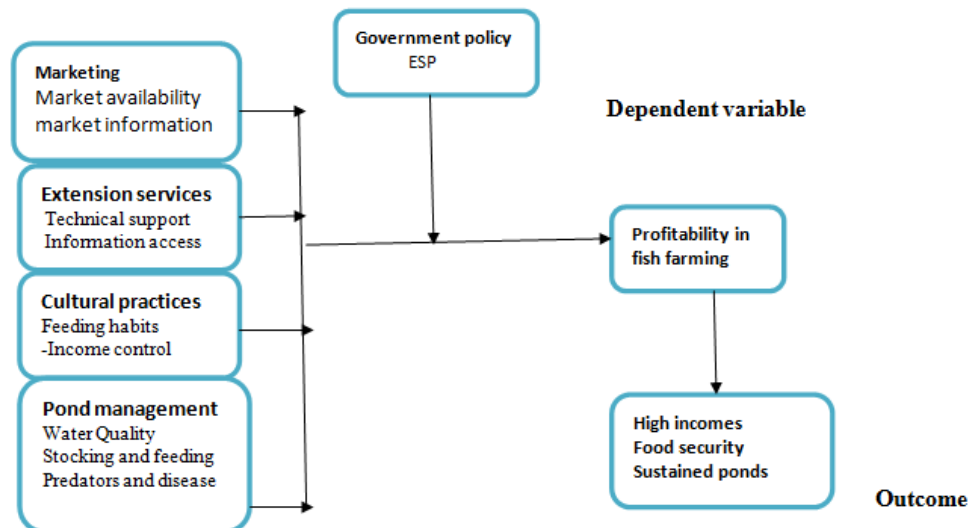

Figure 2.1: Conceptual Framework

Source: Author, 2013

Profitability in fish farming is greatly influenced by independent, dependent and intervening variables. Availability of markets and market infrastructure (marketing), technical support and access to information (technical services), cultural practises such as eating habits and source of income and pond management skills such as on water quality, stocking, feeding and controlling of predators and disease plus the government policy of ESP where farmers funded with Ksh. 40,000 to construct a pond, provided with free 1,000 fingerlings and free fish feeds. All the when combined do influence the profitability of fish farming which is evident in the outcome as witnessed by the high income on fish farming, food security and sustained fish farming.

\section{Research Methodology}

The current study adopted descriptive research paradigm (Kothari, 2004). The design was appropriate to gather information on factors affecting profitability in fish farming in Tigania East district by describing the state of fishing as it existed on the ground. The research targeted a population of 200 fish farmers who were beneficiaries of Economic Stimulus Programme. The list of these fish farmers was obtained from the Ministry of Fisheries Development, Tigania East district. Mugenda and Mugenda (1999) suggest that for descriptive studies, $10 \%$ or above of the accessible population is enough for the study. From the targeted population of 200 respondents the researcher employed scientific method $\left\{\frac{\mathrm{pqZ}^{2}}{\mathrm{e}^{2}}\right\}$ developed by Saunders (2009) and obtained a sample size of 132 respondents for the current study.

The study employed use of questionnaires that were administered to 132 fish farmers who were the first beneficiaries of Economic stimulus programme to capture the information about fish farming during the study. Besides interview schedule was conducted by the researcher on Tigania East district fisheries officer. This was appropriate to add more flesh to questionnaire responses. Instruments validity was ensured through piloting of instruments and split half statistical method was as a test of reliability where, $r=0.79$ was obtained. The data was presented in form of frequencies and percentage, from which inferences and conclusions were made.

\section{Data Analysis And Discussions}

\subsection{Demographic Information and Questionnaire Returns}

A total of One hundred and thirty two (132) questionnaires were distributed to the respondents across the four divisions of Tigania East district and all were returned, this representing a $100 \%$ return rate. This was achieved because of the high rapport that the researcher cultivated among the sampled fish farmers in the study locale.

Table 4.1Gender Distribution of fish Farmers

\begin{tabular}{lll}
\hline Gender & Frequency & Percentage \\
\hline Male & 96 & 72.7 \\
\hline Female & 36 & 27.3 \\
\hline Total & 132 & 100.0 \\
\hline
\end{tabular}


Majority of the respondents were males who represented $72 \%$ while women comprised of $27 \%$ of the total sampled fish farmers. This may be an indicator of who controls the units of ownership and family income in these homesteads.

\begin{tabular}{lll}
\multicolumn{2}{l}{ Table 4.2 } & Farmers' Education Background \\
\hline Level & Frequency & Percentage \\
\hline Primary & 74 & 56.1 \\
\hline secondary & 45 & 34.1 \\
\hline polytechnic & 11 & 8.3 \\
\hline university & 2 & 1.5 \\
\hline Total & $\mathbf{1 3 2}$ & $\mathbf{1 0 0 . 0}$ \\
\hline
\end{tabular}

Statistics from table 4.2 show that most of the fish farmers had studied up to primary school level. This represented $56.1 \%$ of the total sample taken. A further $34.1 \%$ of the respondents had studied up to secondary level and only $1.5 \%$ had gone up to university level. This can be an indicator that the venture is a source of income to the rural people of lower education background and access to market information and related literature on fish farming was scanty.

Table 4.3 Economic of fish Farmers

\begin{tabular}{lll}
\hline Occupation & Frequency & Percentage \\
\hline fish farming & 44 & 33.3 \\
\hline Cattle rearing & 15 & 11.4 \\
\hline Other & 73 & 55.3 \\
\hline Total & $\mathbf{1 3 2}$ & $\mathbf{1 0 0 . 0}$ \\
\hline
\end{tabular}

Of the sampled fish farmers only $33 \%$ of the respondents considered fish farming as the major source of income to their families. Fish farming to most of the farmers is to earn extra income and for subsistence purposes hence their main concern to complement the other sources of income and to bring nutritious food to the family. Majority $55.3 \%$ of the sampled respondents did not have a specified economic activity that performed in life, but jumped from one business activity to the other.

\subsection{Ways in which Marketing of fish Influenced fish Farming}

The first question that the study sought to answer was "In what ways is marketing influencing profitability of fish farming in Tigania East?" Therefore, the fish farmer respondents answered their questions in questionnaires. The responses were categorized, analyzed and tabulated in tables 4.4, 4.5 and 4.6 below.

Table 4.4 Methods of Determining Prices of fish by fish Farmers

\begin{tabular}{lll}
\hline Responses & Frequency & Percentage \\
\hline Prevailing market price & 25 & 18.9 \\
\hline General agreement price among fish farmer & 19 & 14.4 \\
\hline General agreement between buyers and farmers & 80 & 60.6 \\
\hline Others & 6 & 4.5 \\
\hline Missing System & 2 & 1.5 \\
\hline Total & $\mathbf{1 3 2}$ & $\mathbf{1 0 0}$
\end{tabular}

Market price of mature fish is determined by general agreement between buyers and the fish farmers. This was as claimed by a majority $606 \%$ of the fish farmers sampled. A further $18.9 \%$ thought that the prices were set by the prevailing market price. This is an indicator that there is not common bargaining power on the part of the fish farmers as they sell at rural areas by the pond sides where there is low purchasing power by the community.

Table 4.5 below shows that $38 \%$ of the fish farmers sampled thought that the demand for fish was moderate compared to their catch.

Table 4.5 Demand for fish in Tigania East district

\begin{tabular}{lll}
\hline Response & Frequency & Percentage \\
\hline very high & 19 & 14.4 \\
\hline High & 15 & 11.4 \\
\hline Moderate & 50 & 37.9 \\
\hline Low & 45 & 34.1 \\
\hline Very low & 1 & .8 \\
\hline Others & 2 & 1.5 \\
\hline Total & $\mathbf{1 3 2}$ & $\mathbf{1 0 0 . 0}$ \\
\hline
\end{tabular}


A further $34.1 \%$ indicated that the demand was low and still $14.6 \%$ thought the demand was very high. Fish farmers who are able to access market or have ready markets for example those that supply hotels and specific customers in towns indicated that the demand is high, a proof that if market is accessible , market demand would be high thus high profits.

Further, the respondents responded on the question of rates of profits on fish farming as tabulated into table 4.5 below.

Table 4.6 Rates of Profits on fish Farming

\begin{tabular}{llll}
\hline Response & Frequency & & Percentage \\
\hline very high & 9 & 6.8 & \\
\hline High & 10 & 7.6 \\
\hline Moderate & 53 & 40.2 \\
\hline Low & 56 & 42.4 \\
\hline very low & 1 & 0.8 \\
Other & 3 & 2.3 \\
\hline Total & $\mathbf{1 3 2}$ & $\mathbf{1 0 0}$
\end{tabular}

Consistent with the demand for fish, most of the fish farmers felt that the profits were moderate with a further $42.4 \%$ with the opinion that this was low. This might explain why most of the fish farmers are not in this business fully. This may be explained by their low production and lack of market accessibility experienced by the rural fish farmers.

Former respondents provided their views on demand for fish as tabulated in table 4.7 below.

\begin{tabular}{lll}
\hline Table 4.7 & whether demand of fish is determined by culture & \\
\hline Response & Frequency & Percentage \\
\hline Yes & 36 & 27.3 \\
\hline No & 96 & 72.7 \\
\hline Total & 132 & 100.0 \\
\hline
\end{tabular}

Most of the fish farmers indicated that the demand for fish in their areas was not determined by culture as shown by $72.7 \%$ of the respondents, only $27.3 \%$ though that the demand was determined by culture. This was attributed to the empowerment and sensitization on importance of fish as a nutritious diet.

\subsection{Importance of Extension Services on fish Farming}

The second study question was "What is the importance of extension services on fish farming?" Therefore, the fish farmer respondents answered their questions in questionnaires. The questionnaire responses to this question were categorized, analyzed and tabulated in tables 4.8 below.

\begin{tabular}{lll}
\hline Table 4.8 & Frequency of extension officer's visit to fish farms & \\
\hline Response & Frequency & Percentage \\
\hline Frequent & 51 & 38.6 \\
Rarely & 77 & 58.3 \\
Never & 4 & 3.0 \\
\hline Total & $\mathbf{1 3 2}$ & $\mathbf{1 0 0 . 0}$ \\
\hline
\end{tabular}

$58.3 \%$ of the respondents claimed that rarely would extension officers visit them. A further $3 \%$ claim that they have never been visited by an extension officer. This would mean that fish farmers lack the necessary technical information. A fact contributed by low staffing of technical officers in the district and lack of funds to facilitate their movements in the district, for example there is only one extension officer with one motorcycle serving the whole district.

\subsection{Host's Community Cultural Practises Influencing fish Farming}

The third study question that the current research responded to was "What are the host's community cultural practises influencing in fish farming?" Respondents' questionnaire views were categorised, analysed and put in table 4.9 below.

Table 4.9 Government Support to fish Farmers

\begin{tabular}{lll}
\hline Responses & Frequency & Percentage \\
\hline yes & 95 & 72.0 \\
no & 36 & 27.3 \\
Others & 1 & 0.8 \\
\hline Total & $\mathbf{1 3 2}$ & $\mathbf{1 0 0 . 0}$
\end{tabular}


A majority $72 \%$ of the respondents felt that the government supports fish farmers in some way; this may be due to the fact that fish farming is a government initiated programme. Only $27 \%$ of the fish farmers wrote no support was provided. This reasoning could be explained some farmers were far from the district headquarter where the extension worker is based and where all the feeds are stored and farmers have to travel from their areas to come and pick them. Others lack funds to contribute towards cost sharing on part of fingerlings. Majority were of the view that government would provide them with ready market or the storage facilities hence can claim lack of government support.

\subsection{Ways are pond Management Skills Influencing fish Farming?}

The fourth study question was: "In what ways are pond management skills influencing fish farming"? The informants' opinions were analyzed and tabulated in table 4.10 below.

\begin{tabular}{lll}
\hline Table 4.10Problem of Predators in fish Farm & \\
\hline Responses & Frequency & Percentage \\
\hline Yes & 107 & 81.1 \\
\hline No & 23 & 17.4 \\
\hline Others & 2 & 1,5 \\
\hline Total & 132 & 100 \\
\hline
\end{tabular}

A majority $81.1 \%$ of the respondents claimed that predators were a big problem in their fish farms. This could be attributed that most of the fish farmers using fish ponds. Only $17.4 \%$ of the respondents thought that this was not a problem. These predators include birds like kingfisher, frogs, crocodiles, and people. If the fish farmers are not keen and aware these would empty their ponds until the farmer goes for harvesting. Predators can be better controlled by clearing the bushes around the pond and fencing the fish ponds.

Asked whether there were diseases found in the fish ponds, the informants provided the following data in table 4.11 below.

Table 4.11 Presence of fish diseases in fish farm

\begin{tabular}{|c|c|c|}
\hline Responses & Frequency & Percentage \\
\hline Yes & 33 & 25 \\
\hline No & 97 & 73.5 \\
\hline Others & 2 & 1.5 \\
\hline Total & 132 & \\
\hline
\end{tabular}

$73.5 \%$ of the sampled farmers claimed that fish diseases were not common in their farms, with only $25 \%$ claiming diseases were an issue. Others do not know. Fisheries officer informed that fish disease are not common in the district, but there have been cases where ponds have been poisoned by some people of bad motives leading to death of fish and farmers mistake this for fish disease.

\subsection{Cross Tabulations of Related Variables}

4.6.1 Technical Information and Frequency of visits by Extension Officers

\begin{tabular}{|c|c|c|c|c|c|}
\hline \multicolumn{6}{|c|}{$\begin{array}{l}\text { Table4.28: Cross Tabulation of Technical Information and Frequency of visits by Extension Officers to fish Farms in } \\
\text { Tigania East district }\end{array}$} \\
\hline & & \multicolumn{3}{|c|}{$\begin{array}{l}\text { how often do the extension officers visit } \\
\text { your farm }\end{array}$} & \multirow{2}{*}{ Total } \\
\hline & & frequently & rarely & Never & \\
\hline \multirow{2}{*}{$\begin{array}{l}\text { do you have enough yes } \\
\text { technical information to } \\
\text { take care of your fish } \\
\text { farm }\end{array}$} & \begin{tabular}{ll|} 
Count & \\
$\%$ within do you have \\
enough & technical \\
information & \\
\end{tabular} & $\begin{array}{l}43 \\
66.2 \% \\
\end{array}$ & $\begin{array}{ll}22 \\
33.8 \%\end{array}$ & $0 \%$ & $\begin{array}{l}65 \\
100.0 \%\end{array}$ \\
\hline & $\begin{array}{ll}\text { Count } & \\
\% \text { within do you have } \\
\text { enough } & \text { technical } \\
\text { information } & \end{array}$ & 8 & $\begin{array}{l}55 \\
82.1 \%\end{array}$ & 4 & $\begin{array}{l}67 \\
100.0 \%\end{array}$ \\
\hline Total & $\begin{array}{l}\text { Count } \\
\% \text { of who have enough } \\
\text { technical information } \\
\text { on fish farming } \\
\end{array}$ & $\begin{array}{l}51 \\
38.6 \% \\
\end{array}$ & $\begin{array}{l}77 \\
58.3 \%\end{array}$ & $\begin{array}{ll}4 \\
3.0 \%\end{array}$ & $\begin{array}{l}132 \\
100.0 \%\end{array}$ \\
\hline
\end{tabular}

$82 \%$ of those fish farmers who felt that extension officers visited their farms rarely also felt that they don't have enough technical knowhow to take care of their fish farm. A further $66 \%$ of those farmers who felt that extension officer visited them frequently claimed that they had adequate technical knowhow to take care of their fish farm. Thus the more an extension officer visits a farmer the more he/she is likely to report better know how on how to tender the fish farm thus clearly related services and in particular extension service is necessary to keep fish farmers educated on fish farm management. 


\subsubsection{Predators Problem in fish Farm and fish Farming as Profitable Business}

Table 4.32 Cross tabulation of predators problem in fish farm and fish farming as profitable business

\begin{tabular}{|c|c|c|c|c|}
\hline & & \multicolumn{2}{|c|}{$\begin{array}{l}\text { do you consider fish farming to be a } \\
\text { profitable business }\end{array}$} & \multirow{2}{*}{ Total } \\
\hline & & yes & no & \\
\hline \multirow[t]{2}{*}{$\begin{array}{l}\text { are predators a problem in your yes } \\
\text { fish farm }\end{array}$} & $\begin{array}{l}\text { Count } \\
\% \text { within are predators a } \\
\text { problem in your fish farm }\end{array}$ & $\begin{array}{l}34 \\
31.8 \%\end{array}$ & $\begin{array}{l}73 \\
68.2 \%\end{array}$ & $\begin{array}{l}107 \\
100.0 \%\end{array}$ \\
\hline & $\begin{array}{l}\text { Count } \\
\% \text { within are predators a } \\
\text { problem in your fish farm }\end{array}$ & $\begin{array}{l}16 \\
69.6 \%\end{array}$ & $\begin{array}{l}7 \\
30.4 \%\end{array}$ & $\begin{array}{l}23 \\
100.0 \%\end{array}$ \\
\hline Total & $\begin{array}{l}\text { Count } \\
\% \text { within are predators a } \\
\text { problem in your fish farm }\end{array}$ & $\begin{array}{l}50 \\
38.4 \%\end{array}$ & $\begin{array}{l}80 \\
61.6 \%\end{array}$ & $\begin{array}{l}130 \\
100.0 \%\end{array}$ \\
\hline
\end{tabular}

$68 \%$ of those fish farmers who felt that predators were a problem in their farm also felt that fish farming was not a profitable business. This could be attributed to the threat of predators which are eating on to their profit margins. Further $69 \%$ of those fish farmers who felt predators were not a problem also considered fishing a profitable business, this could again be attributed to the reduced risk of predators hence an increased profit margins. We thus see an association between predators (pond management) and eventual profits from fishing, thus we conclude and say that proper pond management would increase the fish output among fish farmers on Tigania east district.

\section{Summary Of Findings And Recommendations}

\subsubsection{The Influence of Marketing on Profitability of fish Farming in Tigania East}

Majority, 57\% of the respondents who felt that the demand for fish was very high compared to the catch also indicated that the prices of fish depended generally on the agreements between the customers and fish farmers. Thus farmers who meet and set fish prices prior to selling their catch were more likely to get higher profits than those who do not. Further $46 \%$ of the fish farmers who felt that the demand was low compared to their catch just agreed on the price of fish between them and the buyer, such farmers are more likely to sell their fish at lower price than the market rate for lack of information and we attribute this to their claim that the demand was low hence leading them to settle for a lower price offered. Thus we conclude and say that lack of market information and marketing is affecting fish farmers negatively in Tigania east district.

$80 \%$ of those farmers who felt that most of their customers are found in urban areas and that their profit earnings were high. This can be attributed to individual farmer efforts to look for market else where like in the urban centres hence again it is notable that those farmers who have access to wider markets for their fish are more likely to get more returns from the venture. This market accessibility is enhanced by the farmers having market information. Therefore it is clear that marketing affects the profitability of fish farming in Tigania East district.

\subsubsection{Importance of Related Extension Services on fish Farming}

Fisheries head in the district reported that farmers are not adequately equipped with technical skills due to the low staffing in the district and lack of funds to facilitate trainings and field visits to impact the knowledge on farmers. Majority of fish farmers also felt that extension officers visited their farms rarely hence they don't have enough technical knowhow to take care of their fish farm. A further $66 \%$ of those farmers who felt that extension officer visited them frequently claimed that they had adequate technical knowhow to take care of their fish farm. Thus the more an extension officer visits a farmer the more he/she is likely to report better know on how to tender the fish farm (Appendix F, figure 4.2) thus clearly related services and in particular extension service is necessary to keep fish farmers educated on fish farm management.

78.9\% of those farmers attend trainings on fish farming in Tigania East District (Appendix F, figure 4.1), claim that fish diseases are not common in their farm, moreover, $65 \%$ of those farmers who don't attend these trainings claim that the diseases are more common in their farms. This was due to lack of knowledge on how to prevent these diseases again we see where there is lack of these extension service, the fish farmer is more likely to suffer we thus in conclusion say that extension services and in this case training affects fish farming where a lack of it would negatively and vice versa.

\subsubsection{The host's community cultural practices that influence fish farming}

Most of the respondents felt that when men are controlling income, there is little fish consumption in their households. They also felt that fish farming was the work of their spouses but a further $51 \%$ who operated fish farming business felt that men controlling income had nothing to affect fish consumption. This result maybe associated to those men who due to their cultural foods have not fully absorbed fish into their main stream diets 
hence have further left the task of fish rearing to their spouses where they happen to have a fish pond. Women being able to access their credit and enlightened more on proper feeding habits/ diets disregarded the norms surrounding consumption of fish and adopted its consumption.

District fisheries officer also observed that some cultural practise though to a less magnitude affected fish consumption. Such practises include the eating habit which termed fish cooking and eating as length procedure, men controlling units of ownership in the family, and availability of other meat sources especially in the district which practise pastoralism and mixed farming.

Thus it can conclude that some cultural beliefs and practices may affect fish consumption patterns in Tigania East district tough not to a large extent.

\subsubsection{Ways in which pond management skills affect fish Farming}

$48 \%$ of those fish farmers who felt that their profits was low also felt that predators were a problem in their farm, a further $52 \%$ of these farmers who felt that predators were not a problem in their also felt that their profits was moderate. Thus there is an association of proper predator control (Appendix F, figure 4.4) as a function of pond management to an increase in profitability of fish as a business venture.

$68 \%$ of those fish farmers who felt that predators were a problem in their farm also felt that fish farming was not a profitable business. This could be attributed to the threat of predators which are eating on to their profit margins. Further $69 \%$ of those fish farmers who felt predators were not a problem also considered fishing a profitable business, this could again be attributed to the reduced risk of predators hence an increased profit margins. This was also noted by the district fisheries officer who noted that predators were a major threat to the venture .Thus there is an association between predators (pond management) and eventual profits from fishing, hence it can be concluded that proper pond management would increase the fish output among fish farmers on Tigania east district.

\subsection{Recommendations}

The study found out that marketing of fish has a positive impact on fish profitability in Tigania East district; hence the government and other stake holders in the fishing ought to develop market information and marketing infrastructure to enhance more market accessibility of fish products.

There is need for extension officers to make frequent visits to the fish farmers as those farmers who were frequently visited by the extension service providers were more aware of fish pond management skills which boosted their returns. Due to the high demand for extension services, the government should also employ more extension officers and facilitate their movements in the field.

There is need to sensitize the community on the benefits of eating fish as evidenced by the emerging eating habits of white meat. There is also a need to empower more women to access units of ownership and income generating opportunities.

The research has found out that training of fish farmers to have a positive relationship to the growth of the fishing industry, therefore more elaborate programs to train fish farmers on pond management skills and modern technology should be developed to enable them.

\subsection{Areas for Further research}

Based on the findings of this survey, the following issues need to be investigated further. These include:

1. The impact of the Economic Stimulus Programme on the fish farmers in Tigania East district.

2. The environmental impact of digging fish ponds in homesteads

3. The social impact on the community as a result of fish farming in the area

\section{Reference}

[1]. Abila, R. (2003). Fish trade and food security: Are they Reconcilable in Lake Victoria? Nairobi, Kenya: Kenya Marine Fisheries.

[2]. Al-Ahram (2010). 20 Million Fingerlings of Nile Tilapia injected in Lake

[3]. Aloo-Obudho, P. A (2010). Contribution of the Fisheries Sector towards Nasser, Cairo, Egypt Kenya. Tropentag: World . Contribution of the Fisheries Sector towards
Food System - A contribution from Europe.

[4]. Brummer, R. E., \& Williams, M. J. (2000). The evolution of aquaculture in African rural and economic development. Ecological Economics, 193-203. [5]. Bushong, J. Gregory, and John C. Talbott. "An Application of the Theory
April 1999.

[6]. Chandran F. (2004) research methodology, methods and technique, New

[7]. Cooper, D. R., \& Schindler, P. S. (2003). Business Research Methods.

[8]. SDey M., Briones Mand Ahmed.M (2005)., Disaggregated analysis of Baseline model and estimated strategy. Aquaculture Economics\& Managen

[9]. FAO (2003) Review of the state of world fishery resources. Rome: FAO

[10]. FAO (2004) The state of world fisheries and aquaculture. Rome: FAO

[11]. FAO (2004b) Aquaculture extension in sub-Saharan Africa. FAO Fisheries Circular. No.1002. Rome, FAO. 55p.

[12]. FAO (2005) Ethical issues in fisheries. Rome: FAO Fisheries. 
[13]. FAO (2005) Small scale aquaculture in sub Sahara Africa: Revisiting the

[14]. FAO (2005) Regional Review on Aquaculture Development: The Near East Italy.

[15]. FAO (2006) Nutritional benefits of fish. www.fao.org/docrep/168, retrieved

[16]. FAO, (2007) Small-scale Freshwater Fish Farming Rome: FAO Fisheries.

[17]. FAO, (2008), The State of World Fisheries and Aquaculture. Rome, Italy:

[18]. FAO, (2009) National Aquaculture Sector Overview: China. Retrieved 2

[19]. GE/WFC, (2005) Government of Egypt/World Fish Center: Strengthening Perspectives; Final Report of $\quad$ Workshop held at Abbassa, $19^{\text {th }}$ June, 2005

[20]. Government of Kenya- Tigania District Development Plan, 2008-2012, government printers-Nairobi

[21]. Government of Kenya- Vision 2030, government printers-Nairobi

[22]. Government of Kenya- Economic Stimulus Programme, government printers- Nairobi (www.stimulus.go.ke)

[23]. Hecht, T. (2006) Regional review on aquaculture development in Sub-Saharan Africa FAO Fisheries Circular. No. 1017/4. Rome pp. 24

[24]. Kapetsky, J.M. (2004) A Strategic Assessment of warm-water fish farming potential in Africa. 67 Rome: Food and Agricultural Organization.

[25]. Kothari C.R (2004) Research methodology, methods and techniques, New Delhi, New Age International (P) ltd

[26]. Macmillan J.H and Schumacher S. (2001) Research in Education, A conceptual Introduction USA Priscilla Mcgeeham

[27]. Mugenda O.M and MugendaA.G (1999) Research methods, Quantitative and Qualitative Approaches,Nairobi ,Act Press

[28]. Muir, J.F., Gitonga, N., Omar, I., Pouomogne, V. and Radwan, I. (2005) Hidden harvests: Unlocking the potential of aquaculture in Africa, Fish for all summit. 22 - 25 August 2005. Abuja, Nigeria. NEPAD

[29]. Mwangi H.M.(2008) Aquaculture in Kenya- Status, challenges and opportunities , Nairobi

[30]. Mwangi, M. H. (2007). A comparative economic evaluation of farming of three important aquaculture species in Kenya. Reykjavik: United Nations University.

[31]. Ngugi, C., Bowman, J. R., \& Omolo, B. (2007). A new guide to fish farming in Kenya. Oregon: USAID.

[32]. Penini M \& Shehadeh Z. (1996), aquaculture in sub Saharan Africa, situation outlook, FAO fisheries circular No. 922 Rome

[33]. Pillay, T.V.R. and Kutty, M.N. (2005) Aquaculture: Principles and Practices.

a. 2nd edn, 625pp Oxford: Blackwell Publishing Ltd

[34]. Rabanal H.R (1989), History of aquaculture, FAO, Rome

[35]. Satia, B. (1989). A regional survey of the aquaculture sector in Africa south of the Sahara. FAO,ADCP/REP/89/36.

[36]. Saunders ,M;Lewis, P and Thornhill, A. (2009), Research methods for Business Students (5 ${ }^{\text {th }}$ edn.) . Harlow: FT Prentice Hall

[37]. Sen, S. 1995. Socio-economic aspects of integrated fish farming. In J-J Symoens \& J.-C. Micha, eds. The Management of integrated freshwater agro-piscicultural ecosystems in tropical areas. Proceedings, p. 465-474. The Netherlands, CTA; Rome, FAO; Belgium, Royal Academy of Overseas Sciences.

[38]. Reynolds, P., Bygrave, W., Erkko, A. \& Hay, M. (2002).Global Entrepreneurship Monitor 2002 Summary Report. Babson Park, MA: Babson College, Ewing Marion Kauffman Foundation and the London Business School.

[39]. Reynolds, P.D, Hay, M., Bygrave, W.D., Camp, S.M., Autio, E. (2000). Global Entrepreneurship Monitor. Kauffman Centre for Entrepreneurial Leadership at the Ewing Marion Kauffman Foundation

[40]. Stickney,R.R. (2005) Aquaculture: An Introductory Text . 256ppWallingford, Oxfordshire, UK: CABI Publishing.

[41]. Vincke, M.(1995), The present state of development in continental aquaculture in Africa. In J-J Symoens \& J.-C. Micha, eds. The Management of integrated freshwater agro-piscicultural ecosystems in tropical areas. Proceedings, p. 27-62. The Netherlands, CTA; Rome, FAO; Belgium, Royal Academy of Overseas Sciences.

[42]. Wairimu P (2008) Voice of Africa - Meru town to Modern fish farming

[43]. Weimin Miao W and Xinhua Yuan X (2007) "The Carp Farming Industry in China - An Overview" In Leung P, Cheng-Sheng Lee $\mathrm{C}$ and O'Bryen PJ (Eds.) (2007) Species and System Selection for Sustainable Aquaculture Blackwell Publishing. ISBN 978-08138-2691-2.

[44]. Williams, M.J.( 1999), The role of fisheries and aquaculture in the future supply of animal protein. Sustainable Aquaculture: food for the future? (eds N. Svennevig, H. Reinertsen \& M. New), pp 5-18. Balkerma, Rotterdam.

[45]. Williams, M.J. \& Poh-Sze, C. (2003), Fisheries Production in Asia: its role in food security and nutrition. IX Asian Congress of Nutrition, New Delhi, India.

[46]. Wilson, E.( 1997), Overfished Oceans, Booming Fisheries: what does this mean for world food security? News and Views International Food Policy Research Unit, Washington, DC.

[47]. World Bank (1986) Poverty and Hunger: issues and options for food security in developing countries. International Bank for Reconstruction and Development, Washington, DC.

[48]. World Bank (2003), Sustainable Aquaculture, Washington, DC.

[49]. Zhijie G, Yingliang X, Xiangguo Z, Yong W, Daobo A and Sugiyama S (2008) Review of fishery information and data collection systems in China FAO Fisheries Circular No. 1029, p. 46. Rome. ISBN 978-92-5-105979-1 